\title{
Performans Ayam Petelur Tua dengan Penggunaan Tepung Ampas Kecap dalam Pakan
}

\author{
Performance of Culled Layer Hen Utilizing Soysauce By-Product Meal in Feed
}

\author{
M. Ramadhan, L. D. Mahfudz, dan W. Sarengat \\ Fakultas Peternakan dan Pertanian Universitas Diponegoro Semarang \\ Jl. drh. R. Soejono Koesoemowardojo, Tembalang, Kota Semarang 50275 \\ Email : mr.ramadhan.47@gmail.com
}

\begin{abstract}
This research aimed to study the effect of utilizing soysauce by-product in old laying hen on feed intake, egg production and feed convertion. The material used were 200 layer hens at 80 week old with average body weight $1932.75 \pm 189.50 \mathrm{~g}$. The research design was completely randomized design (CRD) with 4 treatments and 5 replications. The treatments were T0: feed without soysauce by-product meal, T1: feed with $10 \%$ soysauce byproduct meal, T2: feed with $12.5 \%$ soysauce by-product meal and T3: feed with $15 \%$ soysauce by-product meal. The parameter were to know the feed consumption, egg production and feed convertion. The data was analysed by analysis of variance with $\mathrm{F}$ test, and continous to Duncan multiple range test when there were significant. The result shown that feed consumption, egg production and feed convertion did not significantly affected ( $>0.05)$ by treatments. The conclusion of the research showed that the soysauce by-product meal can be used until $15 \%$ in the layer hen feed.
\end{abstract}

Key word: soybean by-product meal, spent layer, performance

\begin{abstract}
ABSTRAK
Penelitian ini bertujuan untuk mengkaji pengaruh penggunaan tepung ampas kecap dengan level yang berbeda dalam pakan ayam petelur tua terhadap konsumsi pakan, produksi telur dan konversi pakan. Materi penelitian menggunakan ayam petelur umur 80 minggu sebanyak 200 ekor dengan bobot badan rata-rata 1932,75 $\pm 189,50$ gram. Penelitian disusun dalam rancangan acak lengkap (RAL) dengan 4 perlakuan dan 5 ulangan. Perlakuan pakan yang digunakan dengan tepung ampas kecap terdiri dari T0 pakan tanpa tepung ampas kecap, T1 dengan tepung ampas kecap 10\%, T2 dengan tepung ampas kecap 12,5\% dan T3 dengan tepung ampas kecap 15\%. Parameter yang diamati meliputi konsumsi pakan, produksi telur dan konversi pakan. Data hasil penelitian dianalisis ragam dengan uji $\mathrm{F}$ pada taraf uji 5\%, jika ada pengaruh perlakuan nyata dilanjutkan uji wilayah ganda Duncan. Hasil analisis ragam menunjukkan bahwa penggunaan tepung ampas kecap pada ayam petelur tua tidak berpengaruh nyata $(\mathrm{p}>0,05)$ terhadap konsumsi pakan, produksi telur dan konversi pakan. Kesimpulan dari penelitian bahwa tepung ampas kecap dapat digunakan hingga level 15\% dalam ransum ayam petelur tua.
\end{abstract}

Kata Kunci : tepung ampas kecap, ayam petelur tua, performans

\section{PENDAHULUAN}

Ayam petelur adalah ayam yang
secara genetik diseleksi untuk
memproduksi telur dengan baik. Ayam
petelur mulai memproduksi telur pada umur
17-18 minggu dan akan mencapai puncak
produksi pada umur 35 minggu. Produksi
telur akan semakin menurun seiring
bertambahnya umur. Pada umur 80 minggu,
produksi telur berada dibawah $70 \%$.

Produktivitas ayam petelur tua dapat dipertahankan hingga masa afkir dengan perlakuan pakan, salah satunya menggunakan ampas kecap.

Ampas kecap memiliki kandungan senyawa isoflavon yang memiliki kesamaan struktural dengan estrogen yang mampu meningkatkan produktivitas dan kualitas produksi ayam telur. Isoflavon juga berperan sebagai antioksidan dan berperan 
dalam aspek kesehatan ayam petelur. Ampas kecap memiliki kandungan protein kasar $27 \%$, abu $19 \%$, kalsium $0,39 \%$, fosfor 0,33\%, lemak kasar $12 \%$ dan serat kasar 11\%, (Herdiana et al., 2014).

Ampas kecap memiliki kadar garam yang tinggi akibat penggunaan garam pada proses fermentasi kedelai hitam dalam proses pembuatan kecap. Ampas kecap yang akan digunakan sebagai bahan pakan perlu diturunkan kadar garamnya melalui cara perendaman dengan perbandingan ampas kecap $1 \mathrm{~kg}$ : air 21 : asam cuka $6 \mathrm{ml}$ (Sukarini, 2004).

Berdasarkan uraian diatas, maka perlu dilakukan penelitian tentang penggunaan tepung ampas kecap terhadap performans ayam petelur yang meliputi konsumsi pakan, produksi telur dan konversi pakan.

\section{MATERI DAN METODE}

Penelitian dilaksanakan di Balebat Farm, Sukorejo, Kab. Kendal. Materi yang digunakan ayam petelur strain Lohmann Brown umur 80 minggu dengan bobot badan awal 1932,75 \pm 189,50 gram, Bahan pakan untuk menyusun pakan yaitu jagung kuning, bekatul, bungkil kedelai, tepung ikan, poultry meat meal (PMM), meat bone meal (MBM), lysin, metionin, kapur, premix dan ampas kecap. Bahan pakan diformulasikan menjadi pakan dengan mengacu pada Tabel 1. Kandang baterai dengan ukuran 18 x 40 x $45 \mathrm{~cm}$ untuk ayam yang dilengkapi dengan tempat pakan, tempat minum dari paralon PVC. Thermohygrometer untuk mengukur suhu dan kelembaban.

Tabel 1. Susunan pakan dan kandungan nutrisi pakan perlakuan

\begin{tabular}{lrrrr}
\hline \multirow{2}{*}{ Bahan Pakan } & T0 & \multicolumn{2}{c}{ T1 } & \multicolumn{1}{c}{ T3 } \\
\cline { 2 - 5 } Jagung & 55,00 & 55,00 & 55,00 & 55,00 \\
Bekatul & 15,00 & 11,30 & 10,30 & 9,30 \\
Bungkil Kedelai & 15,50 & 12,00 & 10,50 & 9,00 \\
Tepung Ikan & 4,00 & 2,00 & 2,00 & 2,00 \\
MBM & 2,00 & 2,00 & 2,00 & 2,00 \\
PMM & 2,80 & 2,00 & 2,00 & 2,00 \\
Ampas Kecap & 0,00 & 10,00 & 12,50 & 15,00 \\
Lysin & 0,10 & 0,10 & 0,10 & 0,10 \\
methionin & 0,10 & 0,10 & 0,10 & 0,10 \\
Kapur & 4,50 & 4,50 & 4,50 & 4,50 \\
Premix & 1,00 & 1,00 & 1,00 & 1,00 \\
\hline Total & 100 & 100 & 100 & 100 \\
\hline EM & $2.814,20$ & $2.872,86$ & $2.886,79$ & $2.900,71$ \\
PK & 18,83 & 18,98 & 18,93 & 18,88 \\
SK & 5,90 & 6,03 & 6,03 & 6,04 \\
LK & 5,23 & 6,18 & 6,46 & 6,75 \\
Ca & 3,99 & 3,87 & 3,87 & 3,88 \\
P & 0,72 & 0,54 & 0,53 & 0,52 \\
Lysin & 1,08 & 0,96 & 0,94 & 0,91 \\
Methionin & 0,40 & 0,50 & 0,53 & 0,56 \\
\hline & & & &
\end{tabular}


Ayam petelur tua mendapat perlakuan selama 8 minggu, perlakuan yang diberikan berupa pakan T0: Pakan tanpa tepung ampas kecap $0 \%$, T1: Pakan dengan tepung ampas kecap $10 \%$, T2: Pakan dengan tepung ampas kecap 12,5\%, T3: Pakan dengan tepung ampas kecap $15 \%$. Rancangan percobaan dengan rancangan acak lengkap (RAL), dengan 4 perlakuan dan 5 ulangan, setiap unit ulangan berisi 10 ekor ayam petelur tua.

Parameter yang diamati antara lain konsumsi pakan, produksi telur (HDP) dan konversi pakan. Data dianalisis dengan analisis ragam (analysis of varience) dengan uji $\mathrm{F}$ pada taraf $5 \%$, jika ada pengaruh perlakuan nyata dilanjutkan dengan uji wilayah ganda Duncan (Still and Torrie, 1995)

\section{HASIL DAN PEMBAHASAN}

\section{Konsumsi Pakan}

Berdasarkan hasil analisis ragam konsumsi pakan menunjukkan tidak memberikan pengaruh nyata $(p>0,05)$ terhadap konsumsi pakan. Rata-rata konsumsi pakan ayam petelur antara 103,40-105,63g/hari/ ekor. Menurut penelitian yang dilakukan oleh Mangisah et al. (2004) konsumsi pakan ayam petelur dengan tepung pupa sebagai pengganti tepung ikan berkisar antara 103$107 \mathrm{~g}$ /hari/ekor. Ternak mengkonsumsi pakan untuk kebutuhan hidup, meningkatkan bobot badan dan untuk berproduksi (Rusdiansyah, 2014).

Menurut Herdiana et al. (2014) penambahan ampas kecap pada pakan itik tidak berpengaruh nyata pada pertambahan bobot badan, konversi pakan dan konsumsi pakan. Jumlah konsumsi pakan dipengaruhi oleh imbangan energi metabolis dan protein dalam pakan, palatabilitas, dan kondisi fisiologis ayam. Wahju (2004) yang menyatakan bahwa palatabilitas dipengaruhi oleh bau, rasa, tekstur dan suhu makanan yang diberikan.

Kandungan protein yang tinggi dan kandungan antioksidan dalam bentuk isoflavon dalam ampas kecap tidak mempengaruhi konsumsi pakan ayam petelur tua, sehingga dapat digunakan sebagai campuran bahan pakan dalam penyusunan pakan hingga level 15\%. Isoflavon berperan dalam menjaga produktivitas dan mencegah ayam mengalami stress oksidatif. Nurlaila et al. (2013) menyatakan bahwa senyawa isoflavon dapat meningkatkan produktivitas dan kualitas produksi ayam telur, serta berperan sebagai antioksidan dan berperan dalam aspek kesehatan ayam petelur. Malik et al. (2015) menambahkan bahwa isoflavon dapat mengatasi munculnya stress oksidatif yang ditunjukkan dengan produksi telur dan berat telur meningkat serta konversi pakan turun.

\section{Produksi Telur}

Hasil analisis ragam produksi telur menunjukkan tidak memberikan pengaruh nyata $(\mathrm{p}>0,05)$ terhadap produksi telur, disajikan pada Tabel 2. Rata-rata produksi telur berkisar antara 60,54-67,46\% per hari. Menurut Salang (2015) ayam umur 82 minggu harus segara diagkir karena jumlah produksi telur di bawah angka 50\%. Penggunaan tepung ampas kecap hingga 
level 15\% dapat mempertahankan produksi telur ayam tua.

Tabel 2. Hasil analisis ragam konsumsi pakan, produksi telur dan konversi pakan

\begin{tabular}{lccccc}
\hline \multirow{2}{*}{ Parameter } & \multicolumn{5}{c}{ Perlakuan } \\
\cline { 2 - 5 } & T0 & T1 & T2 & T3 & \\
\hline Konsumsi Pakan & $104,34 \pm 4,04$ & $105,63 \pm 3,58$ & $103,40 \pm 4,83$ & $105,54 \pm 2,50$ & NS \\
(g/ekor/hari) & & & & & \\
Produksi Telur (\%) & $61,45 \pm 11,38$ & $60,54 \pm 11,25$ & $61,07 \pm 10,32$ & $67,46 \pm 13,85$ & NS \\
Konversi Pakan & $2,88 \pm 0,52$ & $3,00 \pm 0,84$ & $2,80 \pm 0,44$ & $2,64 \pm 0,59$ & NS \\
\hline
\end{tabular}

Keterangan NS : Non significant

Produksi telur dapat dipengaruhi oleh faktor jumlah pakan yang dikonsumsi ayam, umur, genetik, kesehatan ayam dan lingkungan. Menurut Wahju (2004) produksi telur ayam dipengaruhi oleh genetik, umur, penggunaan obat dan zat makanan dalam pakan terutama asam amino dan asam linoleat, dan kandungan asam lemak linoleat dan metionin. Alwi (2014) yang menyatakan bahwa konsumsi pakan akan mempengaruhi produksi telur, konsumsi pakan yang tinggi akan menghasilkan produksi telur yang baik.

Penggunaan tepung ampas kecap dapat mempertahankan produksi ayam petelur tua. Kandungan isoflavon dalam ampas kecap berperan dalam produksi telur. Nurlaila et al. (2013) menyatakan bahwa senyawa isoflavon dapat meningkatkan produktivitas dan kualitas produksi ayam telur, serta berperan sebagai antioksidan dan berperan dalam aspek kesehatan ayam petelur.

\section{Konversi Pakan}

Berdasarkan hasil analisis ragam konversi pakan menunjukkan tidak memberikan pengaruh nyata $(\mathrm{p}>0,05)$ terhadap konversi pakan. Nilai konversi pakan dapat digunakan sebagai gambaran koefisien produksi, semakin rendah nilai konversi pakan semakin baik, begitu pula sebaliknya, semakin tinggi nilai konversi semakin kurang baik efisiensi penggunaan pakan untuk produksi.

Konversi pakan untuk ayam petelur antara angka 2,0 - 2,2 dan semakin kecil nilai konversi pakan maka semakin efisien pula ayam tersebut dalam memanfaatkan pakan untuk memproduksi telur (Prawitya et al., 2015). Risnajati (2014) menyatakan bahwa beberapa hal yang dapat mempengaruhi nilai konversi pakan antara lain kondisi lingkungan kandang, manajemen pemeliharaan termasuk manajemen pemberian pakan, produksi telur serta konsumsi pakan tiap harinya.

\section{KESIMPULAN}

Kesimpulan dari penelitian bahwa tepung ampas kecap dapat digunakan hingga level $15 \%$ dalam ransum ayam petelur tua. 


\section{DAFTAR PUSTAKA}

Alwi, W. 2014. Pengaruh Imbangan Energi Protein Terhadap Performa Ayam Arab. Fakultas Peternakan, Universitas Hasanuddin. Makassar.

Herdiana, R. M., Y. Marchal., R. Dewanti dan Sudiyono. 2014. Pengaruh penggunaan ampas kecap terhadap pertambahan bobot badan harian, konversi pakan, rasio efisiensi protein dan produksi karkas itik lokal jantan umur delapan minggu. Buletin Peternakan 38 (3) : 157 156.

Mangisah, I., I. Estiningdriati dan S. Sumarsih. 2004. Konsumsi pakan dan produksi telur akibat penggantian tepung ikan dengan tepung pupa dalam ransum. J. Indo. Trop. Anim. Agric. 29 (1) : 39 43.

Nurliana., Razali., C. Fani. 2013. Efek pemberian pakan yang mengandung ampas kedelai terfermentasi Aspergillus niger terhadap ketebalan kerabang telur ayam kampung (Gallus domesticus). J. Med. Vet. 7 (2) : 64-66.

Prawitya, A. S., H. Natsir dan O. Sjofjan. 2015. Pengaruh penambahan probiotik Lactobacillus sp.
Bentuk tepung dalam pakan terhadap kualitas telur ayam petelur. J. Ilmu - Ilmu Peternakan. 4 (1): 1 - 8.

Risnajati, D. 2014. Pengaruh jumlah ayam per induk buatan terhadap performan ayam petelur strain isa brown periode starter. J. Sains Peternakan. 12 (1): $10-14$.

Rusdiansyah, M. 2014. Pemberian Level Energi dan Protein Berbeda terhadap Konsumsi

Ransum dan Air serta Konversi Ransum Ayam Buras Fase Layer. Fakultas Peternakan, Universitas Hasanuddin. Makassar.

Salang, F., L. Wahyudi, E. Queljoe, D. Y. Katili. 2015. Kapasitas ovarium ayam petelur aktif. J. MIPA Unsrat Online 4 (1) : 99-102.

Sukarini, N. E. 2003. Studi penggunaan ampas kecap yang diproses dengan larutan asam asetat untuk pakan terhadap komposisi kimia dan karakteristik fisik daging ayam broiler. Fakultas Peternakan, Universitas Diponegoro. Semarang.

Wahju, J. 2004. Ilmu Nutrisi Unggas. Cetakan ke-5. Gadjah Mada University Press, Yogyakarta. 